\title{
REINVESTING IN HAVANA: HOUSING COMMODIFICATION AND GENTRIFICATION IN THE CENTRAL NEIGHBOURHOODS OF A SOCIALIST CITY IN THE GLOBAL SOUTH
}

Violaine Jolivet is an Associate Professor at the Université de Montréal. Her work in urban and social geography focuses on the links between mobility and urban production in the Americas. She is the author of a book Miami the Cuban, Geography of a Crossroad-City between the Americas (published in French in 2015) and published several articles about gentrification and urban revitalization policies in a critical perspective in Miami, Havana and Montreal.

Mateo Alba-Carmichael is a geographer and cartographer from the University of Montreal. Regarding Cuba, he has worked alongside Violaine Jolivet since 2017 for the project "(Re)investing Havana", mainly analysing and mapping data. He also worked as an intern for the Group for the Integral Development of the Capital (GDIC) in Havana in 2020. His current interests include cities' social and regional development, and macroeconomic degrowth.

\begin{abstract}
This article addresses the commodification of housing in Havana from 2011 onwards. It argues that the theories of gentrification and rent-gap can illuminate aspects of the transformation of the Cuban capital, even though these theories originated in capitalist urban contexts and that in Cuba the state is responsible for determining the value and ownership of land. The analysis of digital real estate ads on four platforms between 2012 and 2020 allows us to estimate the price and location of properties sold, their relationship to economic reinvestment in the central areas of the city, and how the geographic factors that define centrality are increasingly compromised by touristification and more generally by the commodification of housing. The urban transformations studied in this initial article on the real estate
\end{abstract}


market and gentrification in the Cuban capital allow us to highlight that, on one hand, the transformation of housing into a commodity demonstrates the erosion of socialist values in urban production and, on the other, the creation of a real estate market in Havana has reinforced the connection of the Cuban city with transnational capitalist circulation. The article considers the economic and political context in which the market develops, then explains the methodology of big-small data in a context of limited access to information, followed by an analysis characterising Havana's market that examines the importance of spatial centrality and transnational flows of people and capital.

Keywords: housing, commodification, gentrification, digitalisation, post-socialist city

In Cuba, since November 2011, Decree-Law 288 allows Cuban citizens to sell and purchase houses on the island, respecting the limit that an individual can only own two properties at a time (main and vacation), which has been in place since the beginning of the Cuban Revolution. This legal limit protects the housing sector from uncontrolled economic liberalisation that would favour some wealthy owners or investors (local or foreign) who, in most capitalist or post-socialist markets, have been key players in the accumulation of real estate and financialisation of the housing sector, particularly in recent decades (Aalbers 2019). Now that Havana has a real estate market, it can be compared to other emerging real estate markets, including those in (post-)socialist cities. ${ }^{1}$ In Cuba 85 percent of the population owns the property in which they live and real estate speculation and mortgage credit were abolished early in the 1959 revolution (Trefftz 2011), so to reintroduce a real estate market and its socioeconomic mechanisms 50 years later turns this into a historic opportunity to witness and analyse the broader economic and social changes taking place on the island (Brenner et al. 2014; Pérez 2014; Pleyán 2020). The commodification of housing is relevant to understanding the market-oriented transformations on the island, as well as the acceleration of privatisation and liberalisation in

1 Although incomplete, this categorisation of cities in countries that have been or are still governed by communist regimes designates a relationship between a specific spatial entity: the city and its suburbs, and an ideological, political, economic and social system: socialism. Some of the characteristics of socialist cities are a predominance of public land and state-managed investment and reduced socio-spatial segregation (French and Hamilton 1979; Szelenyi 1996; Hirt 2013). 
a state whose latest Constitution, from 2019, firmly reaffirms the country's socialist character.

In this article, an examination of the real estate market reveals Havana's urban transformations and uncovers the erosion of socialist values in urban production, attesting to the increasing connection to globalised capitalism, leading to the fragmentation of the city. This research, mainly done in the central municipalities of Havana's urban area, shows how the reintroduction of a real estate market has resulted in new forms of capitalisation of housing, affecting urban space, differentiating the value of land and transforming the neighbourhoods and thus the daily life of their inhabitants. This is creating new socio-spatial differences in a city that was long-considered "frozen" in time and to have largely deteriorated. In this way, as Lefebvre (1991) states and as also emphasised by C. Pleyán, this article reiterates the contradictions of liberalising the sale/purchase of the housing stock in a socialist city without previously establishing a land law. "On the one hand, there is no home that is not associated with a piece of land and that does not include the land value in its total financial value. On the other hand, the precise location of that property in a given city and, in a specific area, regardless of its intrinsic values (materials, date of construction, etc.) also affects its value" (Pleyán 2020: 140, free translation from Spanish).

As market-oriented reforms are being reintroduced in Cuba and an exchange value is given back to housing, often homes that need major repairs are worthless and only the land and location have value, and the asking price set by the seller. Most of the population in Havana, even if they have or own the roof over their heads, are not really in a position to buy real estate because they do not have the economic means to improve their current living conditions ${ }^{2}$ or because this is not one of their urgent priorities. Although there is a great need for housing, it begs the question of who can participate or invest in this market? One clue identified by several experts is the growth of the private sector on the island in recent decades, which has increased significantly since the 2011 Guidelines to encourage private investment, which were later enshrined in the 2019 Constitution. Another reason is that the Cuban diaspora has been investing in the domestic economy

2 In 2020, the average monthly salary is Cuba was 879 Cuban pesos (\$37 USD) according to the state-run National Statistics Office (ONEI). In 2021, Cuba unified its monetary system to only use the Cuban peso. The country's minimum wage is to be set at 2,100 Cuban pesos per month (\$87 USD) (ONEI 2020). 
(Hansing and Orozco 2014; Henken and Vignoli 2017; Wijburg et al. 2020). Several analyses show two main groups of buyers: (1) Cubans with very limited labour income and spending capacity who need to acquire a basic property in which to live, and (2) Cubans, Cuban dual-citizens and foreigners with sufficient capital who want to buy better housing for themselves, run a business on the property or speculate in real estate (Pleyán 2020).

Based on H. Lefebvre's (1991) reflections about the production of space and the right to the city, centrality can be defined as an urban form but also as the essence of the urban condition, criticising how capitalism is a threat for social and cultural dimensions of centrality. Our research question is the following: how is urban centrality being defined and influenced within the process of recapitalisation in Havana (knowing that the revolutionary city planning measures were implemented to ensure territorial equity between the centre and the periphery)? This research on inner-city neighbourhoods addresses both the question of gentrification and touristification, ${ }^{3}$ which generate new forms of socio-spatial inequalities through the commodification of housing.

The first part of the article briefly presents the theoretical framework on gentrification. The second part presents the context of this study: the economic, legal and geopolitical transformations that characterise the birth of the real estate market in Havana. The third part explains the methodology and presents our database of 7,075 housing ads, explaining what it contains and how it was collected, in a context of limited access to data, using the concept of "small big data". Fourth, the analysis presents the asking prices of properties for sale, their characteristics and the geographic and statistical distribution of real estate ads between 2012 and 2020. It also describes the real estate market in Havana and the distribution of prices in the city by location, highlighting the strong contrast between the centre and the periphery and indicating gentrification processes. The fifth part analyses the role of centrality in the market value of housing and shows how the central neighbourhoods have more real estate activity not only because of the quality of the buildings, but also because of the potential land value. The last part looks at the effects of global capitalism on the real estate market, starting in tourist spaces (state-owned or private) and heritage areas, to

3 Touristification is defined as the transformation of space for use by tourists instead of considering the needs of the local population. 
spatialise some market hotspots, while underlining that what is marketed in housing sales is not only centrality, but also the usufruct or the service produced by the use of the property.

\section{Havana and Gentrification Studies}

Gentrification implies a population shift consisting of the displacement/substitution of the existing population by new users or inhabitants with socio-economic characteristics above those of the former users and residents. These population shifts are accompanied by a transformation in the public and commercial space and the built environment through renovation and reinvestment of capital in impoverished neighbourhoods or places where previously investment had ceased. Despite the fact that the theory of gentrification originated in the Global North, it can be considered as a global concept, as acknowledged by Loretta Lees and other colleagues (2016), and can be applied to a city like Havana. The literature on gentrification is now very broad. The classical schools of thought in this field have been distinguished by causal explanations, on the one hand based on the transformation of the middle classes and their tastes (Ley 1996), and on the other, driven by capitalist dynamics on modes of production of the city and the transformation of property and land supply (Smith 1987, 2002). Although the two approaches are complementary, and there is no single causal process, the theoretical anchor of this study agrees that the gentrification theories of capital centralisation and rent-gap can illuminate particular aspects of urban transformation in the Cuban capital and detect certain dangers associated with major changes such as lack of access to land and housing, and consequences such as eventual displacements or not being able to find housing in suitable neighbourhoods (López-Morales 2015).

Rent-gap is based on a Marxist analysis of urban production processes; it indicates that the current value of land or property is lower than its potential value, which can then lead to gentrification. This differential motivates a process of capital return or reinvestment in certain areas of the city, where capital gains can be maximised (Smith 1979, 1987; Slater 2017), because those areas previously had a period of disinvestment, where rents and the price of land and buildings had decreased. In the case of Havana, where the revolution barred the private sector and its interests from playing a role in the determination of land value and ownership, the analysis looks at the role played by the state and urban centrality (determined by the concentration of economic, cultural and tourism activity) in real estate pricing (Hackworth and Smith 2001). This paper also attempts to verify the applicability of gentrification studies applied to a specific context: a socialist city in the Global South. 
Work done by urban geographers in cities of the former Soviet Bloc, among other places, has shown how the reintroduction of private property, the advent of real estate operations led by public-private partnerships and the opening of urban production to international players have transformed cities and led to the growth of new socio-spatial segregations (Rudolph and Brade 2005; Stanilov 2007; Sýkora 2009; Andrusz et al. 2011). Studies on post-socialist cities have also revealed processes of gentrification, although these did not develop in the same way as in capitalist Western hemisphere cities. They also highlight the importance of taking into account different urban temporalities that impact post-socialist cities and the many different players that control the urban reconquest (Kubeš and Kovács 2020).

Likewise, observations in European post-socialist contexts at different periods are similar to those described in some of the literature on processes of gentrification and urban renewal in cities of the Global South. Asian (Shin et al. 2016) and Latin American (López-Morales et al. 2016) studies allow us to highlight the diversity of contexts in which reinvestment occurs in city centres and above all they allow us to perceive the complexity of the processes involved. While highlighting the specificities of socio-spatial inequalities and power relations in the metropolises of the South, it is necessary not to group distinct urban processes under the same label of gentrification (Lopes de Souza 2016). Some researchers consider that gentrification is specific to the global cities of the North and that it should not be applied to postcolonial cities (Maloutas 2017).

In Havana, two types of processes can be distinguished and connoted as gentrification, even though this is an emerging phenomenon. (1) On one hand, a group has emerged that has access to capital (through transnational family remittances and increased self-employment) and the real estate market has been partially liberalised, which has made it easier for families with greater purchasing power to achieve residential mobility and replace poorer households, particularly in the central municipalities that were historically the places of residence for the middle and upper classes before the Revolution, such as Vedado, Playa and Miramar. The replaced populations move to other surrounding or suburban neighbourhoods. (2) On the other hand, there is also gentrification linked to Havana's tourism economy that plays an important role in the gentrification of certain central neighbourhoods, where resident families are replaced by landlords who wish to reserve rooms or whole homes for rental to foreign tourists (Witjburg et al. 2020). This phenomenon is evident in Old Havana where the neighbourhood's high heritage value (classified as a UNESCO world heritage site) and tourist development in the area are 
often mentioned as selling points. These processes of touristification and heritagisation also situate Havana amongst international studies on gentrification and tourism (Gravari-Barbas and Guinand 2017). In fact, since the 2000s, research conducted in Old Havana evidences state-sponsored "capitalisation" for development through tourism (Rutheiser 2000; Hill 2007; Herrero 2007), which has led to inquiry into this Cuban city's new relationship with the commodification of housing and globalisation (Edge et al. 2006; Bailey 2008). In recent decades, authors have often described Havana as having growing inequalities, mainly due to the existence, since the mid-1990s, of a dual economy with the creation of the convertible peso, or CUC, indexed to the US dollar, introduced especially in tourist areas, as well as the sharp increase in money transfers and consumer goods sent from outside the island. Consequently, there are important inequalities between Cubans who have access to these economic circuits linked to tourism and the global economy, and those who do not have these transnational relations (Scarpaci et al. 2002). More recently, the article by Wijburg et al. (2020) situates Havana within the analysis of emerging markets and processes of commodification and financialisation that highlight the significance of transnational dynamics.

\section{Market Reforms in Cuba and Housing Commodification}

The Cuban state has been dealing with a major housing crisis since the early days of the revolution. Several policies have been implemented to address this shortage: from increased access to prefabricated building materials (1960-70), self-construction programmes by microbrigades (temporary groups of builders working together to build housing for their families) (1970-80), to the delivery of building materials for households affected by hurricanes or the creation of social housing and housing cooperatives (Trefftz 2011; Rabinovich 2010; Rego 2018). Although 85 percent of Cuban households own the property in which they live, and therefore could potentially participate in the housing market, the emerging housing market is developing in the context of a housing crisis mainly due to overcrowding and young couples wanting to be independent. The housing situation has been a major challenge on the island and in Havana in particular for several decades (Rego 2018).

Even though the revolutionary state has sponsored the construction of hundreds of thousands of housing units since 1960, the construction rate has always been lower than the population growth rate (Mesa-Lago 2017). In Havana, with 2.1 million inhabitants, the situation is even more difficult (Pleyán 2020: 137). 
In the capital, where the vast majority of buildings were constructed before the Revolution and few repairs have been done, many dwellings are in poor condition; falling short, in one way or another, of urban habitability standards (Iñiguez 2014; Pleyán 2020). This research focuses on the central municipalities of Habana Vieja, Centro Habana, Playa and Plaza. These municipalities are characterised by very high building and population densities and old buildings of considerable heritage value, especially in the colonial neighbourhoods of Centro Habana and Habana Vieja. ${ }^{4}$ This complicates modifications and repairs, on top of the difficulties finding materials at a fair price and also labour, even though the state has recently facilitated repair projects by partly liberalising construction work (Mesa-Lago 2017). The supply of cement and other basic construction materials remains complicated, in part due to the embargo imposed by the United States since 1962 .

\section{Cuba Post-1989, a Slow and Heterogeneous Economic Opening towards the Market}

The opening of the real estate market reflects a context of change on the island. Although liberalisation processes and privatisation have been increasingly visible since the 2010s, these processes are rooted in the political and economic changes that have been taking place since the 1990s, such as the collapse of the Soviet Bloc and Cuba's need to survive economically after the USSR, its main trading partner, disappeared. There are also the influential US trade and financial embargoes that have been in place since 1962. Cuba's economic opening cannot be understood without considering that it is an island that has been under US economic embargo for almost 60 years (Jolivet 2017).

The literature on the transition to a capitalist economy in socialist countries has largely highlighted the slowness of Cuba's opening towards a market economy and how the concept of transition has lagged in application (Whitehead and Hoffman 2016). The transformation of the Cuban economy and its opening to globalised capitalism has been more timid than the experiences of Vietnam or China, which since the 1980s and 1990s have maintained political and institutional control (through a single party and very similar government structures) but while establishing a connection to the world

4 In 2016, the population density in the municipality of Centro Habana was 40,368 hab/ km²; Habana Vieja 19,298 hab/km²; Playa 5,044 hab/km²; and Plaza de la Revolución 11,883 hab/km² (ONEI 2017). 
economy at a brisk pace (Scarpaci 2000; Mesa-Lago 2013; Vidal 2016). Certainly, the 1990s in Cuba, corresponding to the Special Period in Time of Peace, was a period of deep crisis for the country, in which structural transformations were prevented and economic development was focused on specific sectors. The opening to mass tourism, the development of biotechnology, the birth of joint ventures (arising from associations between foreign companies and the Cuban state) to generate investments, the emergence of small private enterprises and the creation of the CUC indexed to the US dollar were some of the initiatives implemented at a time when the embargo was again reinforced with the Torricelli Law (1992), which sought to slow down the growth of the new engines of the Cuban economy. The dual currency economic system, which came to an end at the beginning of the year 2021, was one of the measures long criticised for having created two economic systems and widening the inequalities between Cubans who have access to this currency (from remittances or work in specific sectors such as tourism or small private enterprise) and others (Holbraad 2017; Bastian 2018).

\section{Updating the Cuban Model}

The transfer of power from Fidel to Raúl Castro in 2008 coincided with an acceleration of economic reforms, without abandoning the socialist model. Academics and experts inside and outside the island have highlighted a diversification of the players and factors driving economic growth during the 2000s that has been reinforced by the 2011 Guidelines (Sánchez Egozcue and Triana 2008; Brenner et al. 2014; Bobes et al. 2015). As indicated by Cuban economist Triana, three lines of action for "updating" of the country can be identified:

- The delegation of economic control through the creation of cooperatives and the partial privatisation of several sectors of the economy (in particular the urban economy).

- The "restructuring and modernisation of the state apparatus" through decentralisation processes and transformations of various ministries (Triana 2012: 86-7, free translation)

- "The eradication of prohibitions" on trade, which includes improving telecommunications (including the internet) on the island, the creation of a "private market for [imported] automobiles and the creation of a private housing market which, together with changes in immigration law, should contribute improving the people's situation" (Triana 2012: 86-7, free translation). 
The 2011 Guidelines and subsequent laws increased the number and sectors in which licenses are granted to cuentapropistas - a euphemism for entrepreneurs and reformed regulations on foreign investment, and also validated the liberalisation of the real estate market (Hamberg 2012; Pleyán 2020). The right to buy and sell a house is enshrined in the 2019 Cuban Constitution signed by President Díaz-Canel. The 2011 amendments to the General Housing Law known as Decree-Law 288, and the 2017 amendments to Decree-Law 343 on fiscal instruments (specifying how housing value is officially assessed so that it can be taxed at 4 percent) are the legal instruments used in this research to understand the political economy that gives context to the birth of Havana's real estate market.

It is worth mentioning that the amended housing laws that authorised the sale and purchase of real estate arose from a growing need to make it easier for families change homes. This demand was initially met by inter-family housing exchange laws, known as permutas. However there was also a need to take into account the fact that monetary payments were often part of the housing exchanges, which had been illegal under the previous housing exchange laws (Núñez 2008). Therefore, one of the main motivations to authorise buying and selling was to tax the cash transactions that were previously taking place alongside home exchanges (Pleyán 2020). The intention was not to create an environment favourable for investors; the real estate investment market was an unavoidable consequence of the partial liberalisation of this sector of the economy.

\section{Transnational Connections and their Impact on Economic Openness}

It is important to consider the geopolitical context in addition to the internal transformations. The alliance with Venezuela, ${ }^{5}$ the creation of the ALBA (Bolivarian Alliance for the Americas) economic coalition and increasing foreign trade and investment from China (Mesa-Lago and Vidal 2019) have been transforming Cuba's relational geography since 2000 (Jolivet 2017).

5 In 2017, trade with Venezuela represented about 12 percent of Cuba's Gross Domestic Product (GDP). As noted by Jimenez Enoa (2019), as of that year, when the US embargo tightened and the crisis in Venezuela got worse, the amount of oil that Venezuela had been sending Cuba since 2002 was reduced by half. Since then, one of the priorities of the Cuban government has been to strengthen bilateral ties with China. 
New transnational flows of money, goods and people with the United States, and the role of the diaspora are also important for understanding the ways the island is connecting with the exterior and Cuba's international dynamics (Bobes et al. 2015).

The transition of power to Raúl Castro, as well as the Democrats' arrival in the White House in 2008, made travel easier for transnational families and made it possible to link economic flows on both sides of the Florida Strait (Hansing and Orozco 2014; Jolivet 2017). In 2009, the Obama administration announced the lifting of restrictions on travel and remittances that the Republican had strictly limited. He also ended the "Commission for Assistance to a Free Cuba" that had been set up by George W. Bush to reinforce the embargo. Obama made it easier for US nationals to travel to the island by granting licenses to individuals under twelve categories for travel. In September 2015, the process of normalisation was accelerated; the limit on remittances was lifted, US businesses could partner with Cubans, sell equipment to the private sector and open offices on the island. At the same time, US banks were allowed to open accounts for Cuban citizens and US companies could open accounts in Cuba. In 2016, following Obama's historic visit to Havana, authorisation for recreational and cruise travel between Cuba and the United States was signed. In the final weeks of his second term in office, President Obama, in accordance with the terms of negotiation with the Cuban government, ended the "Wet feet/dry feet" policy, a law that allowed undocumented Cubans who arrived in the United States to obtain permanent US residency the following year. Following this, "there was a sharp drop in illegal departures and, at the same time, fewer houses were put up for sale by people who hoped to raise capital to finance the process of emigration and settling in the new country" (Pleyán 2020: 141, free translation). After his election, President Trump implemented policies that once again cracked down hard on Cuba at a time when reductions in oil imports and trade with Venezuela had already dealt a serious blow to the country's economy (Mesa-Lago and Vidal 2019). In addition to renewing the economic embargo, in particular the Helms-Burton Act, the Republican administration increased travel restrictions for US citizens, prohibited certain financial transactions, recreational travel and barred cruise ships from landing in the island (US Embassy 2017). These restrictions had a strong impact on Cuba's tourism sector, reducing the number of tourists coming from the United States, which had grown exponentially since 2016 . The restrictions therefore reduced the number of visitors staying in hotels and private homes in the Cuban capital (Perrelló Cabrera 2019).

The COVID-19 pandemic subsequently dealt another blow to the island's tourism economy and therefore it likely also impacted the private real estate sector. 
This context introduces the scope of the analysis of the real estate market. On the one hand, it is essential to understand the reforms towards greater commoditisation of housing and the rise of the private sector in order to analyse the situation in which the market develops. On the other hand, the importance of transnational relations, especially those of Cuban-Americans, and the tourism industry, even when these exhibit considerable variations as the result of geopolitical and global forces, are important factors to consider in order to analyse the data and answer the previously mentioned research questions.

\section{Methodology: Access to Information and Data on Havana's the Real Estate Market}

\section{Small-Big Data, Data Production and Digitisation of the Real Estate Market}

In Cuba, the only way to find out about the number of real estate transactions and their location is to access the notarial deeds of sale. The deed of sale lists the official sale price (reference value) in Cuban pesos (CUP) and the 4 percent transfer of goods and inheritances tax, which both the buyer and the seller have to pay. But it is almost impossible to have access to this information, and even more so for a foreign researcher. The reference value is calculated in accordance with Decree-Law 343, based on the physical characteristics and location of the house. However, the market value of a property may be more than ten times higher than the official reference value, and often is in Havana's central municipalities (Pleyán 2020). The "official” price derives from a fixed formula, however the market price fluctuates based on the property's physical characteristics, location, investment potential, national and international policies and economic trends in local, and even global, real estate markets. This means that the reference value, on which the transfer tax is collected, is often considerably lower than the amount of money that actually changed hands, therefore the documented reference value does not accurately represent property values.

The difficulty of obtaining a large amount of accurate information about real estate market prices in Cuba, in order to do substantial quantitative analysis, made it necessary to analyse the prices listed in real estate advertisements published online in a context of digitalisation of the real estate market (Fields and Rogers 2019), similar to other analysis on the use of digital data in the context of the Global South (Milan and Treré 2019). Although the data come from property ads, and it is not known if the property sold or not, or the final price, the data collected are not arbitrary; this data make it possible to get an idea of the real market price. Through web scraping, thousands of ads in Havana were collected every month for a total of close to 30,000 ads, but many of these ads 
were duplicates that remained on the websites from one month to the next. There were also ads that did not indicate the asking price or mention the geographical coordinates, which were necessary to build the database. ${ }^{6}$ Finally, after filtering the ads, a total of 7,075 was reached. Other real estate sites and even Facebook pages were also consulted to compare the prices with the ones collected, although that information was not used in the analysis.

The sample collected of 7,075 ads that had appeared over five years (2015-20) may seem small, especially for Havana which accounts for more than 80 percent of Cuba's market. Given the lack of data, and as a result of critical and feminist reflections in geographic information sciences and data processing, it was appropriate to apply Gieseking's concept of big-small data (2018). In this case, the lack of a pre-existing database of this type in Cuba makes this sample even more valuable. Despite the limitations, the data gathered are big enough, within the given context (Gieseking 2018), and are of real scientific interest when placed in the socio-historical context of data production and collection on real estate in Cuba. The data collected clearly represent only part of the total number of real estate sales. The final sale price in each transaction is also unknown, but in a context in which this information is not available, the intention was to create a chronological and relatively large database. Therefore, the calculations indicate the published sale price, not the actual sale price, meaning it is an indicator of value from the seller's perspective of what the property could potentially be worth.

\section{Website Selection and Database Development}

The websites chosen were those with the largest number of ads, where new ads were constantly being published. The information needed was extracted by web scraping. Ad data were mainly obtained from detrasdelafachada.com, porlalivre.com and espaciocuba.com, in addition to some from cubahomesdirect.com and havanakeys.com. After 2017, the websites of espaciocuba, cubahomesdirect and havanakeys disappeared and others emerged, such as cubisima and other platforms with a significant housing section, such as revolico.com which has a large number of ads every day for Havana. The data extracted from each ad were price and geographic location (with longitude and latitude coordinates from the website html). In addition, when available further data were collected on: type of real estate (apartment or house), number of rooms, number of bathrooms, area in $\mathrm{m}^{2}$, apartment floor, year of construction, street address, the URL

6 Only a few websites indicated the geographic coordinates for each ad, essential for the GIS analysis. 
of the ad and its date of publication. The descriptive paragraphs about the property, written by each advertiser, were also collected.

Between 2015 and until mid-2017, all the data in the ads from porlalivre, cubahomesdirect and havanakeys were extracted manually by copying and pasting it into a table. As of 2017, in addition to manually extracting information from porlalivre ads, web scraping was used for the websites detrasdelafachada and espaciocuba, which include geographic coordinates for each ad, for which reason these websites were prioritised. Surprisingly, there was information available from more than 800 old ads that had been published between 2012 and 2014. Web scraping was expanded to cover the entire province of Havana as of 2018, providing more context on the evolution of the real estate market in the central neighbourhoods in relation to the rest of the city.

\section{Methodological Limits}

The database provides an overall view of the characteristics and evolution of the market, based on what is available on the internet. It is, therefore, only a partial view of everything that is advertised and sold. This is a limited view of the city's total real estate market. Real estate activity that indicates residential mobility is much greater than the 1,500 annual ads processed in this database. Currently, most real estate transactions are not done through internet platforms, but rather through "For Sale" signs in windows, face-to-face real estate markets and brokers. It should also be mentioned that the permuta, an action legally authorised since the beginning of the Revolution to exchange housing, is still being used. However, as the work of urban economist R. Núñez shows, the permuta, which officially does not include a monetary transaction, was the first mechanism that made it possible to estimate the exchange value of housing and land in Cuba. Prior to the 2011 authorisation to freely sell and purchase property, the permuta had

proved to be very effective in incorporating hidden and informal valuations and transactions in housing, and monetary interests are increasingly appearing as an important feature.... The transactions within the permuta now even incorporate aspects that anticipate future value increments and other benefits and profits from the development of home based businesses, or aspects that anticipate positive impacts derived from public investments or new urban regulations. (Núñez, 2012: 91)

We do not know what share real estate advertisements on the internet represent with respect to the total number of advertisements in the real estate market, but it can be assumed that their importance is increasing as the Cuban population has more internet access (Venegas 2010; Jolivet 2017) and that there is an 
increase in investors-buyers from abroad. Like any real estate advertisement, the quality of the advertisement and the veracity of the information available depend on the advertiser.

\section{Commodification of Housing in Havana: What is Being Sold, Where and at What Price?}

Based on the 7,075 ads, the median asking price was 45,000 CUC (equivalent to US dollars), while the mean asking price was 78,247 CUC. This indicates that certain properties are posted at a much higher asking price than the median.

Figure 1 shows the frequency distribution of the ads according to their asking price in intervals of 5,000 CUC. This graph shows that the mode of the price distribution is only 20,000 CUC. It may also be seen that most of the housing transactions in Havana are in the range of 15,000 to 40,000 CUC, but that simultaneously half of the ads exceed 45,000 CUC, and 10 percent of the ads have an asking price greater than 160,000 CUC.

The map in Figure 2 shows the price distribution of real estate for sale according to each municipality and neighbourhood. Focusing on the city centre, it is clearly observed that almost all of Plaza de la Revolución and most of Miramar have asking prices above Havana's average and that Centro Habana is almost entirely below the average. It is observed how the heritage zone of Habana Vieja exhibits prices above average, while in the same municipality the impoverished neighbourhood of Jesús María, further inland from the bay and surrounded by industrial areas, is below the average. Prices in a large part of Diez de Octubre, the most populated of Havana's 15 municipalities, are also below average, while

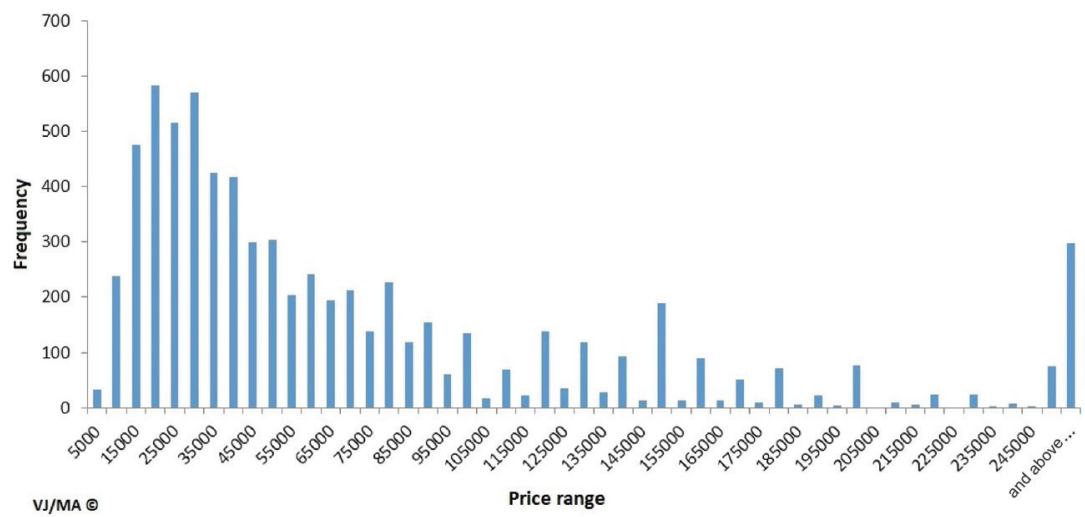

Figure 1 Histogram of number of advertisements per price range 


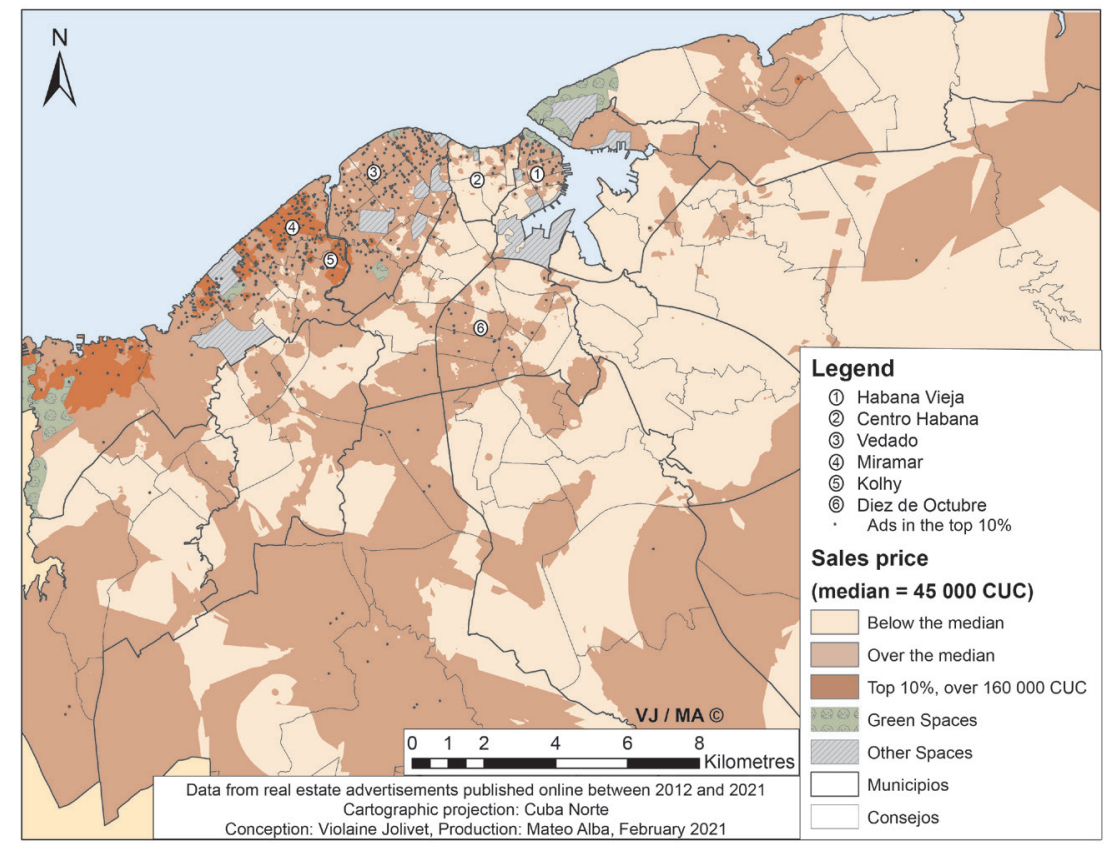

Figure 2 Price interpolation according to the asking price of properties advertised on the internet

areas some within it are above average, such as La Víbora, founded during the colonial period. This map also shows where the most expensive 10 percent of ads are located, mainly in the central neighbourhoods, and which areas that have an average price above the 90th percentile. Thus, the old bourgeois neighbourhoods, where properties are large and the constructions are of high quality and architectural value, such as in Miramar and Kolhy clearly stand out on this map; this is where most of the city's political and military elites still reside and foreign embassies are found.

Investment is coming back to these historically bourgeois neighbourhoods, following an era in which the urban laws brought in at the start of the Revolution and when the upper classes fled to Miami, increased the social mix of these residential neighbourhoods. In fact, the 1960 urban reform, which for a long time was the only document that guided urban development in Cuba, illustrated the goal of Castro's policies: to reset economic balance in the country by bringing less affluent people to live in the wealthy capital city (Suman 1987). The longevity of the Revolution had a major impact on the redefinition of Havana's landscape, especially through the drastic reduction of commercial activity and the 


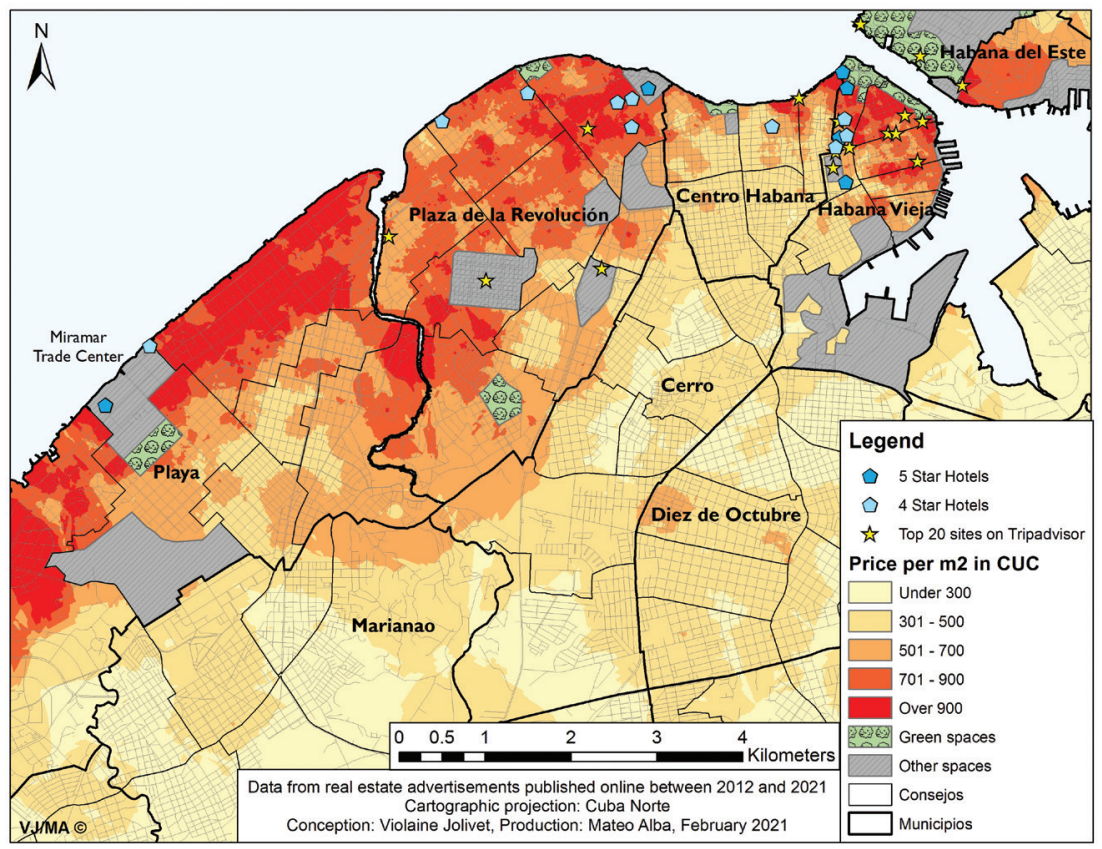

Figure 3 Interpolation map of prices per square metre in Havana

"equitable" distribution of housing, which clearly favoured "de-bourgeoisisation" and a socio-spatial homogenisation of the city (Eckstein 1977; Slater 1982).

The analysis of asking prices throughout the city indicates the importance of the urbanity of the neighbourhoods' location in the city, but does not provide detail on role of local urban spaces in the process of reinvestment of private capital in the city. In order to compare prices in different neighbourhoods, we must compare the prices per square metre (Figure 3).

The map of prices per square metre shows how, in addition to Miramar or Kholy, other neighbourhoods stand out, particularly Vedado, as well as some areas of Centro Habana and Habana Vieja where housing is smaller but mostly dates from the colonial period. In this visualisation of the distribution of prices per square metre, it is clear that there is a centre/periphery factor that affects real estate prices and that the reintroduction of an exchange value for housing promotes spatial differentiation in prices that does not represent the usage value and laws on land ownership established by the state. Location can increase property value and also indirectly generate a rent surge, therefore demonstrating forms of capitalist differentiation or fragmentation of urban space. According to 
Hammel's study on rent-gap (1999), it can be assumed that the prices of poor and dilapidated downtown neighbourhoods increase due to reinvestment in those locations, which increases the economic potential in the entire central area.

\section{Are Havana's Central Districts the Most Coveted Spaces? Recapitalisation of Centrality}

Although capitalisation in Havana has not consisted of a growing monopolisation of property by a select number of individuals, nevertheless the market's space, and therefore capital, is concentrated within the city's central districts.

Figure 4 shows the evolution of prices per square metre, differentiating the four central municipalities from the others. The dashed curve representing the period prior to 2015 indicates a lower reliability in the data, because the data referring to the period between 2012 and 2015 was collected a posteriori and there is less of it. The figure clearly shows that the municipalities of Plaza de La Revolución and Playa, with the exception of Centro Habana, are always above the average price for Havana, while the prices in the municipalities outside our main study area are below this average, and are therefore more affordable or impoverished neighbourhoods. Habana Vieja is still very heterogeneous and exhibits a more irregular curve, having both a hyper-tourist area and other very degraded pockets, but since 2017 its prices per square metre have been higher than Havana's average. The heterogeneity of the properties for sale and their condition and size, in each of the central municipalities, logically influences the average price per square metre. However, centrality remains a key indicator in

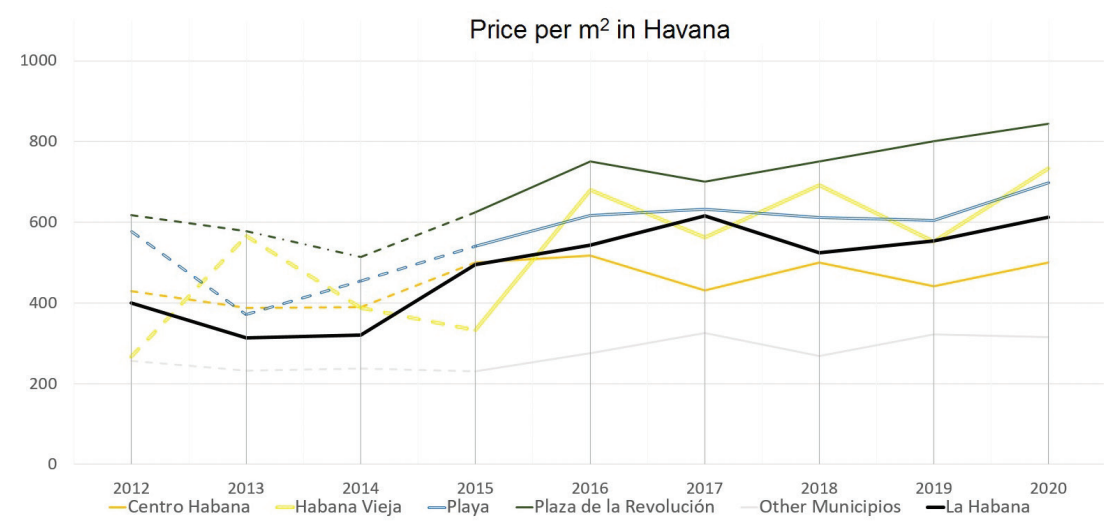

Figure 4 Evolution of the price per square metre in Havana in CUC 
the characterisation of Havana's market, where even the most rundown central districts have much higher prices than others, as shown by data from 2020 where Centro Habana has an average price of $500 \mathrm{CUC} / \mathrm{m}^{2}$ while the average price in the non-central municipalities is of $333 \mathrm{CUC} / \mathrm{m}^{2}$. In comparison, the other central municipalities have average prices of $696 \mathrm{CUC} / \mathrm{m}^{2}$ in Playa, 756 $\mathrm{CUC} / \mathrm{m}^{2}$ in Habana Vieja and $838 \mathrm{CUC} / \mathrm{m}^{2}$ in Plaza de La Revolución.

Another factor that makes it possible to see types of capital reinvestment in real estate in the central municipalities is the greater market activity in these locations. The Havana municipalities with the largest numbers of listings are Plaza, Playa and Diez de Octubre. In fact, in 2020 the municipality of Plaza de La Revolución alone contained 21.9 percent of all ads in Havana. The four municipalities mainly studied account for 54.2 percent of all ads in Havana in a space that occupies 7.7 percent of the province's area and where 25.9 percent of its population lives. These central municipalities in Havana dominate the real estate market of the capital city and the country, which indicates that rent-gaps are closing (Smith 1979). Although Havana's current reinvestment phase is far from the scale and intensity seen in the metropolises of the Global North, on which most academic studies are based, it seems that the concentration of supply and the greater commodification of housing in Havana's central municipalities is due in part to speculation and the higher potential value of real estate in these areas. This is a common characteristic of reinvestment zones in cities of the Global North. Examining the rent-gap makes it possible to understand differences in price and market activity, highlighting the central areas as the main targets of real estate investment.

\section{Touristification and Housing Commodification: Havana's Transnational}

\section{Perspective}

In this section, it is important not to limit the analysis of reinvestment to a spatial conceptualisation of urban centrality, but also to focus on urban space as a factor that contributes to price. Here the role of transnational flows of capitalism should be considered, in particular tourism and remittances that have constituted main sources of foreign exchange in the country since the 1990s. Through this reconnection, flows of global capitalism are impacting places with outstanding architecture and shifting the city towards the market, thus transforming urban centrality into capitalist and tourist centrality. These same zones are often urban spaces in which the state, in association with foreign firms, reinvests in the city to attract financial flows, signs of a metropolisation that has begun in Havana. The market has begun to fragment the space and this is clearly visible in the urban landscape. Examples include the state-sponsored Miramar 
Trade Centre complex that has been under development since 1999 and the large state-owned (fully state-owned or a majority share) four and five-star hotels (Figure 5) that have flourished in recent years, attracting foreign capital flows into areas that later become investment zones, which makes it possible to consider the role of the state in the capitalisation of urban space (Hackworth and Smith 2001, López-Morales 2019).

As the analysis of prices per square metre shows, most of the large hotels and international tourism and investment areas identified on the Tripadvisor platform are almost uniformly surrounded by areas with the highest prices, above $700 \mathrm{CUC} / \mathrm{m}^{2}$ (Figure 3). This is particularly visible in Old Havana, a UNESCO World Heritage site, the northern part of which is a tourist hyper-centre and where the state began the process of recapitalisation in the 2000s (Rutheiser 2000; Bailey 2008). These recapitalisation zones, through tourism and economic development promoted by the state, start to make the surrounding blocks more attractive. This effect increases the potential value of these areas in the real estate market, in particular when accompanied by better maintenance of public spaces and improvements to utility services, such as stabilising water and electricity supply.

Finally, one of the last factors that is essential to take into account when analysing real estate prices in Havana's central areas is the potential to transform housing into a commodity through usage, particularly in the case of houses turned into private restaurants (Henken and Vignoli 2017) or more commonly

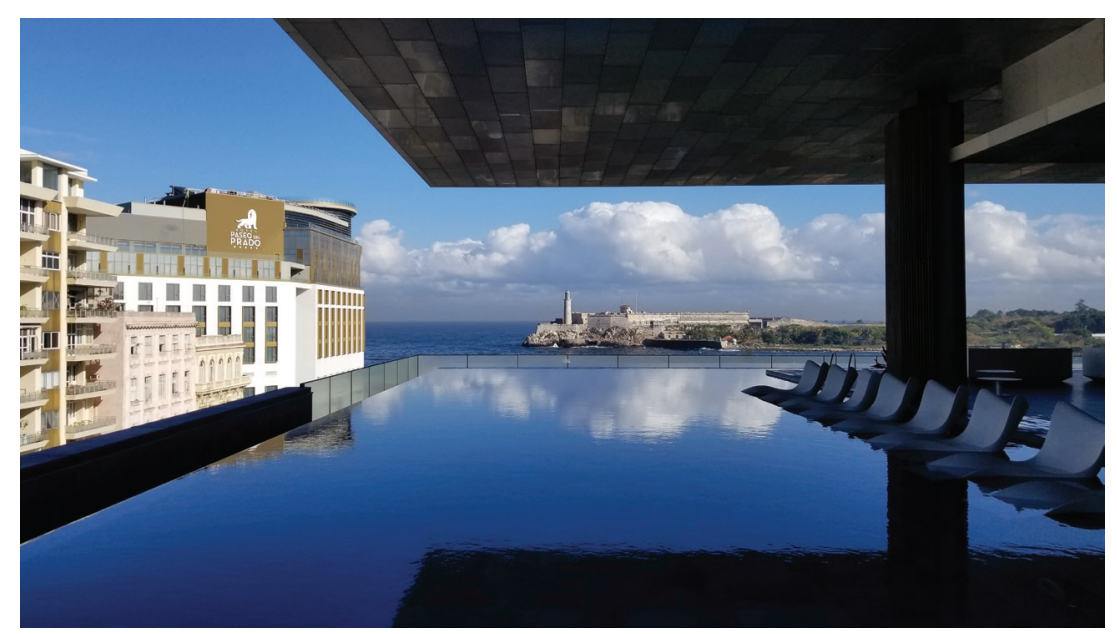

Figure 5 Hotel 5* Paseo del Prado from the pool of the Iberostar Grand Packard. Old Havana, 2020 (C) Violaine Jolivet 
as rentals for tourists (casas particulares). The commodification of housing favours the transformation of numerous properties into "tourism properties", where those with money to invest can take advantage of the rent-gap (Wijburg et al. 2020). Consequently, the possibility that private individuals can use housing stock to generate revenues by exercising private economic activity or by facilitating transnational investment is essential to understanding this market. It is clear that real estate investment is also linked to forms of commodification of housing, since the value of housing is no longer based solely on its intrinsic characteristics but also on the possibility of benefiting monetarily from it, especially in the context of the growth of urban tourism in Havana and increasing selfemployment. The rise of the tourism property market is connected with remittances and other forms of foreign investment, which shines a light on transnational gentrification and the conversion of housing in Cuba into financial assets (Pleyán 2020; Wijburg et al. 2020).

A look at the Airbnb database (Figure 6), authorised in Cuba since 2015, shows the importance of this process of transformation of housing into a commodity for rent revenue and the large increase in the number of rooms or entire homes no longer available to city residents, but now intended for tourists or foreign visitors. Both Cuban nationals and Cubans with transnational family members are buying housing, furnishing it and offering it on digitised rental platforms. Gentrification through tourism and commodification of housing led

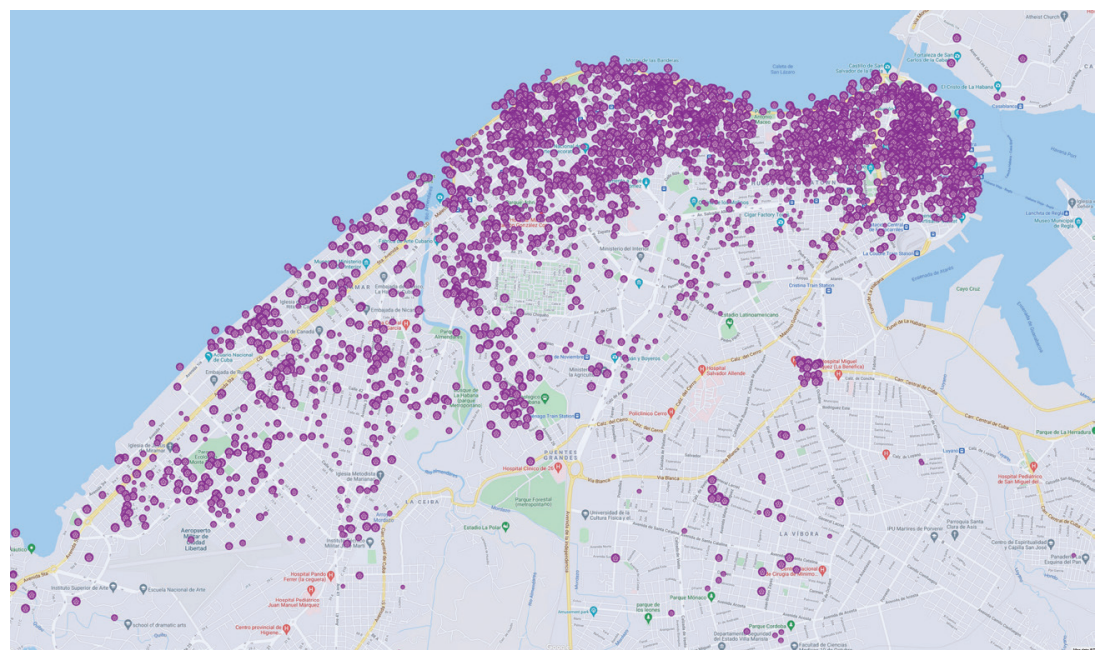

Figure 6 Location of entire dwellings available for temporary rental according to Airbnb's RDNA database, February 2021. 
to an increase in restrictions on the exchange, title transfer, sale and purchase, and construction of housing in "areas of high significance for tourism", according to resolution 133 of the housing law of July 2018, which applies to the municipalities of Centro Habana and Habana Vieja, intended to "maintain the balance of the resident population and avoid its increase" (Gaceta Oficial 2018, free translation).

\section{Conclusion}

The analysis of asking/purchase prices, price range and geographic distribution, between 2012 and 2020, has revealed a constant increase in the price per square metre throughout Havana, even given the effects of the Cuban context. This is evident in Havana's central neighbourhoods, which have the highest prices in the market and the greatest number of properties for sale. The high asking prices in central Havana, compared to the other municipalities, indicates that these central neighbourhoods are particularly attractive to those who have the financial means to invest in them (the self-employed, transnational families and foreigners with front-men), which means that, due to market forces, the exchange value of housing has increased, and its use value reflects the demand of housing commodification. The higher monetary valuation of housing in the central neighbourhoods will probably contribute to the displacement of poorer households to other municipalities in the city where prices are more affordable, which was not addressed in this study but merits further investigation. The market's concentration in the central areas makes it possible to observe forms of gentrification induced by investment motives, because the properties' centrality gives them potential value, which implies higher returns on the investment for the buyers. This research on the digitised market made it possible to present a unique kind of emerging gentrification in an area where this subject has previously not been studied. This article also provides the results of the analysis of unpublished data that, although limited, is valid within the concept of small-big data. This makes it possible to observe the evolution of Havana's real estate market and the commodification of housing in the socialist capital.

The analysis also made it possible to assess the effects of the geographical divisions brought about by this new cycle of real estate investment, as well as the onset of what Lefebvre (1991) called the fragmentation of space for sale and purchase. This fragmentation is still incipient in Havana's urban space. It is taking place through the development of areas destined essentially for tourism and by attracting transnational capital flows, both processes being concomitant. 
For more than 50 years, the socialist state outlawed real estate speculation. The new real estate market is still in its early stages and it requires careful handling in order to address the issue of gentrification and rent-gap. Creeping elitism is gradually taking over the streets of Havana's central neighbourhoods, and although the state continues to prevent monopolisation of the urban space by private interests, housing commodification is taking place. These processes are only a part of the real estate market where local investors are also important, even if they have little capital. This market remains young and is in constant evolution between liberalisation and state regulation. In this sense, the recommendations by Carlos García Pleyán (2020) are pertinent: update and publicise cadastral data; strengthen the instruments of control by the municipality and the province of Havana over the building transformations in progress; and maintain strict laws preventing ownership of multiple properties.

This analysis was done in the midst of the COVID-19 pandemic and after monetary reunification in Cuba. Two issues became apparent during recent months, which are important in analysing the mechanisms that drive the future commoditisation of housing:

1). The transformation of housing into a financial asset is not only the result of the transnationalisation of the market, but is also because of Cuban buyers whose fear of inflation after monetary reunification pushed them to invest in a property because of their considerable distrust of the nationalised banking system.

2). The importance of transnational ties (including tourism) in the commodification of housing makes the recapitalisation of urban space and the transformation of housing into a commodity unstable and heterogeneous. Evidence of this is the rapid sale of a number of properties marketed for tourism that have been empty since the start of the pandemic, sometimes at prices lower than those observed at the beginning of 2020 .

\section{Acknowledgement}

The authors would like to thank the comments and reviews of Matari Pierre and Ernesto López-Morales, as well as the anonymous reviewers of the journal for their relevant contributions to this version of the article. They also warmly thank Leslie Carmichael for her help in the translation of the article into English and Jeimy Arias for rereading the Spanish version. 


\section{References}

Aalbers, M. (2019) "Introduction to the forum: From third to fifth-wave gentrification", Tijdschrift voor Economische en Sociale Geografie, 110(1): 1-11. Available at: https:// doi.org/10.1111/tesg.12332.

Andrusz, G., Harloe, M., and Szelenyi, I. (2011) Cities After Socialism: Urban and Regional Change and Conflict in Post-Socialist Societies. Hoboken, NJ: John Wiley \& Sons.

Bailey, N. (2008) "The challenge and response to global tourism in the post-modern era: The commodification, reconfiguration and mutual transformation of Habana Vieja, Cuba", Urban Studies, 45(5-6): 1079-96. Available at: https://doi.org/10.1177/ 0042098008089854.

Bastian, H. (2018) Everyday Adjustments in Havana: Economic Reforms, Mobility, and Emerging Inequalities. Lanham, MD: Rowman \& Littlefield.

Bobes, V., Mesa-Lago, C., Chaguaceda, A., Geoffray, M., Alfonso, H., and Rojas, R. (2015) Cuba: ¿Ajuste o transición? Impacto de la reforma en el contexto del restablecimiento de las relaciones con Estados Unidos. Mexico: FLACSO.

Brenner, P., Jiménez, M., Kirk, J., and LeoGrande, W. (2014) A Contemporary Cuba Reader: The Revolution under Raúl Castro. Lanham, MD: Rowman \& Littlefield.

Eckstein, S. (1977) “The debourgeoisement of Cuban cities", in Louis Horowitz (ed.), Cuban Communism. New Brunswick, NJ: Transaction Books, 445-63.

Edge, K., Scarpaci, J., and Woofter, H. (2006) "Mapping and designing Havana: Republican, socialist and global spaces", Cities, 23(2): 85-98.

Fields, D., and Rogers, D. (2019) "Towards a critical housing studies research agenda on platform real estate", Housing, Theory and Society, 1-23.

French, R., and Hamilton, F. (1979) The Socialist City: Spatial Structure and Urban Policy. Chichester: John Wiley \& Sons.

Gaceta Oficial (2018). Ley General de la Vivienda 2018, resolución 133.

Gieseking, J. (2018) "Size matters to lesbians too: Queer feminist interventions into the scale of big data", The Professional Geographer, 70(1): 150-6. Available at: https:// doi.org/10.1080/00330124.2017.1326084.

Gravari-Barbas, M., and Guinand, S. (eds) (2017) Tourism and Gentrification in Contemporary Metropolises: International Perspectives. Abingdon: Taylor \& Francis.

Hackworth, J., and Smith, N. (2001) "The changing state of gentrification", Tijdschrift voor Economische en Sociale Geografie, 92(4): 464-77. Available at: https://doi. org/10.1111/1467-9663.00172.

Hamberg, J. (2012) "Cuba opens to private housing but preserves housing rights", The Environment, 19(1): 6.

Hammel, D. (1999) "Gentrification and land rent: A historical view of the rent gap in Minneapolis”, Urban Geography, 20: 116-45.

Hansing, K., and Orozco, M. (2014) "The role and impact of remittances on small business development during Cuba's current economic reforms”, Desigualdades, 69. Available at: http://dx.doi.org/10.17169/refubium-23425.

Harvey, D. (2001) Spaces of Capital: Towards a Critical Geography. Abingdon: Routledge. 
Henken, T., and Vignoli, G. (2017) "A taste of capitalism? Competing notions of Cuban entrepreneurship in Havana's Paladares”, Human Geography, 10(3): 97-114. Available at: https://doi.org/10.1177/194277861701000308.

Herrero, G. P. (2007) “Crisis, posmodernidad y planificación estratégica en La Habana”, Anales de geografía de la Universidad Complutense de Madrid, 27(2): 135.

Hill, M. (2007) "Reimagining Old Havana: World heritage and the production of scale in late socialist Cuba", in Saskia Sassen (ed.), Deciphering the Global: Its Scales, Spaces and Subjects. New York: Routledge, 59-78.

Hirt, S. (2013) "Whatever happened to the (post)socialist city?", Cities, 32: 29-38.

Holbraad, M. (2017) "Money and the morality of commensuration: Currencies of poverty in post-Soviet Cuba", Social Analysis, 61(4): 81-97. Available at: https://doi. org/10.3167/sa.2017.610406.

Iñiguez, L. (ed.) (2014) Las tantas Habanas . . .: estrategias para comprender sus dinámicas sociales. Havana: Editorial UH.

Jiménez Enoa, A. (2019) “China: el nuevo benefactor de Cuba”, Diálogo Chino. Available at: https://dialogochino.net/es/comercio-y-inversiones-es/31432-china-el-nuevo-benefactor-de-cuba/.

Jolivet, V. (2017) “Nouvelles mobilités à Cuba : Penser l'espace relationnel cubain à l'heure du rétablissement des liens avec les États-Unis", Cahiers des Amériques latines, 84: 49-67.

Kubeš, J., and Kovács, Z. (2020) “The kaleidoscope of gentrification in post-socialist cities”, Urban Studies, 57(13): 2591-2611. Available at: https://doi.org/10.1177/ 0042098019889257.

Lees, L., Shin, H., and López-Morales, E. (2016) Planetary Gentrification. Cambridge: Polity Press.

Lefebvre, H. (1991) Le droit à la ville. Paris: Anthropos.

Ley, D. (1996) The New Middle Class and the Remaking of the Central City. Oxford: Oxford University Press.

Lopes de Souza, M. (2016) "Gentrification in Latin America: Some notes on unity in diversity”, Urban Geography, 37(8): 1235-44.

López-Morales, E. (2015) "Gentrification in the global South", City, 19(4): 564-73. Available at: DOI: 10.1080/13604813.2015.1051746.

López-Morales, E., Shin, H., and Lees, L. (2016) "Latin American Gentrifications", Urban Geography, 37(8). Available at: https://doi.org/10.02723638.2016.1200335.

López-Morales, E. (2019), "State-Led Gentrification" in The Wiley-Blackwell Encyclopedia of Urban and Regional Studies. Available at: https://doi.org/10.1002/ 9781118568446.eurs0321

Maloutas, Thomas (2017) "Travelling concepts and universal particularisms: A reappraisal of gentrification's global reach", European Urban and Regional Studies, May. Available at: https://doi.org/10.1177/0969776417709547.

Mesa-Lago, C. (2013) "Panorama de las reformas económico-sociales y sus efectos en Cuba", Cuba in Transition (Association for the Study of the Cuban Economy), 23: $1-15$.

Mesa-Lago, C. (2017) “La vivienda en Cuba socialista y las reformas estructurales”, Cuba Posible. Available at: https://cubaposible.com/vivienda-cuba-socialismo-reformas/. 
Mesa-Lago, C., and Vidal, P. (2019) "El impacto en la economía cubana de la crisis venezolana y de las políticas de Donald Trump.” Real Instituto Elcano, DT, 9.

Milan, S., and Treré, E. (2019) "Big data from the South(s): Beyond data universalism”, Television and New Media, 20(4): 319-35. Available at: https://doi.org/10.1177/1527476419837739.

Núñez, R. (2008) "La Permuta: An effective instrument for housing transactions in Cuba”, IHS Working Papers, 19.

Núñez, R. (2012) “Urban land management in Cuba”, PhD diss., Utrecht: Uitgeverij Digitalis.

ONEI (2017) "Datos de la Provincia de La Habana”, Anuarios Estadísticos Municipales. Available at: http://www.onei.gob.cu/?q=mapa/provincia/habana (accessed 25 February 2021).

ONEI (2020) Salario Medio en Cifras Cuba 2019. Available at: http://www.onei.gob.cu/ sites/default/files/salario_medio_2019_completa.pdf

Pérez, L. (2014) Cuba: Between Reform and Revolution. Oxford: Oxford University Press.

Perrelló Cabrera, J. (2019) “El turismo en Cuba: cambios y tendencias”, Cuba Horinzonte. Available at: https://horizontecubano.law.columbia.edu/content/el-turismo-en-cubacambios-y-tendencias.

Pleyán, C. (2020) "El mercado inmobiliario en cuba: Carencias legislativas y tributarias - The real estate market in Cuba: Legislative and tax deficiencies", International Journal of Cuban Studies, 12(1): 135-48. Available at: https://doi.org/10.13169/intejcubastud.12.1.0135.

Rabinovich, A. (2010) "Los intereses sectoriales de la vivienda social en Cuba”, EchoGéo, 12.

Rego, R. (2018) "La Habana, dinámica socio espacial de las formas urbanas”, PatryTer, 1: 1-12.

Robinson, J. (2002) "Global and world cities: A view from off the map", International Journal of Urban and Regional Research, 26(3): 531-54. Available at: https://doi. org/10.1111/1468-2427.00397.

Rudolph, R., and Brade, I. (2005) "Moscow: Processes of restructuring in the post-Soviet metropolitan periphery”, Cities, 22(2): 135-50.

Rutheiser, C. (2000) "Capitalizing on Havana: The return of the repressed in a late socialist city", in G. Brudge and S. Watson (eds), A Companion to the City. Oxford: Blackwell, 224-36.

Sánchez Egozcue, J., and Triana, J. (2008) “Un panorama actual de la Economía Cubana, las transformaciones en curso y sus retos perspectivos”, Boletín Elcano, 104: 45.

Scarpaci, J. (2000) "Reshaping Habana Vieja: Revitalization, historic preservation, and restructuring in the socialist city", Urban Geography, 21(8): 724-44.

Scarpaci, J., Segre, R., and Coyula, M. (2002) Havana: Two Faces of the Antillean Metropolis. Chapel Hill, NC: UNC Press.

Shin, H., Lees, L., and López-Morales, E. (2016) "Introduction: Locating gentrification in the global east”, Urban Studies, 53(3): 455-70.

Slater, D. (1982) "State and territory in post-revolutionary Cuba: Some critical reflections on the development of spatial policy", International Journal of Urban and Regional Research, 6(1): 1-34.

Slater, T. (2017) "Planetary rent gaps", Antipode, 49: 114-37.

Smith, N. (1979) "Toward a theory of gentrification: A back to the city movement by capital, not people", Journal of the American Planning Association, 45(4): 538-48. 
Smith, N. (1987) "Gentrification and the rent gap", Annals of the Association of American Geographers, 77(3): 462-5.

Smith, N. (2002) "New globalism, new urbanism: Gentrification as global urban strategy", Antipode, 34(3): 427-50.

Stanilov, K. (ed.) (2007) The Post-Socialist City. Urban Form and Space Transformations in Central and Eastern Europe after Socialism, 92. Berlin: Springer Science \& Business Media.

Suman, P. (1987) "Spatial equality in Cuba", International Journal of Urban and Regional Research, 11(2): 218-42.

Sýkora, L. (2009) "New socio-spatial formations: Places of residential segregation and separation in Czechia", Tijdschrift voor Economische en Sociale Geografie, 100(4): 417-35.

Szelenyi, I. (1996) "Cities under socialism - and after", in Cities After Socialism: Urban and Regional Change and Conflict in Post-Socialist Societies. Hoboken, NJ: John Wiley \& Sons.

Trefftz, E. (2011) "50 años de la ley de reforma urbana en Cuba. En el aniversario del cambio de paradigma", Revista INVI, 26(72): 19-62. https://doi.org/10.4067/invi. v26i72.558.

Triana, J. (2012) “Cuba: ¿de la “actualización” del modelo económico al desarrollo?” Nueva Sociedad, Democracia y Politica en América Latina, 242: 82-91. Available at: https://nuso.org/articulo/cuba-de-la-actualizacion-del-modelo-economico-al-desarrollo/ US Embassy in Cuba (2017) "Hoja informativa sobre la política respecto a Cuba", Embajada de los Estados Unidos en Cuba, 17 June. Available at: https://cu.usembassy. gov/es/hoja-informativa-sobre-la-politica-respecto-cuba/.

Venegas, C. (2010) Digital Dilemmas: The State, the Individual, and Digital Media in Cuba. New Brunswick, NJ: Rutgers University Press.

Vidal, Pavel (2016) "Cuba's Reform and Economic Growth: A Comparative Perspective with Vietnam", Journal of Economic Policy Reform, 19(2): 148-65. Available at: https://doi.org/10.1080/17487870.2015.1119046.

Whitehead, L., and Hoffman B. (eds) (2016) Debating Cuban Exceptionalism. Berlin: Springer.

Wijburg, G., Aalbers, M., and Bono, F. (2020) "Cuban migrants and the making of Havana's property market”, Urban Geography, 1: 1-26.

Zhou, M., and Logan, J. (1996) "Market transition and the commodification of housing in urban China", International Journal of Urban and Regional Research, 20(3): 400-21. Available at: https://doi.org/10.1111/j.1468-2427.1996.tb00325.x. 